Scientia Agricola

http://dx.doi.org/10.1590/0103-9016-2015-0294

\title{
Bacterial strains from floodplain soils perform different plant-growth promoting processes and enhance cowpea growth
}

\author{
Elaine Martins da Costa $^{1}$, Fernanda de Carvalhoํㄹ Rafaela Simão Abrahão Nóbrega², Jacqueline Savana Silva ${ }^{1}$, Fatima Maria de \\ Souza Moreira ${ }^{1 *}$
}

${ }^{1}$ Federal University of Lavras - Dept. of Soil Science - Sector of Biology, Microbiology and Biological Processes, C.P. 3037 - 37200-000 - Lavras, MG - Brazil.

${ }^{2}$ Federal University of Recôncavo da Bahia/Center of Agrarian Sciences, Environmental and Biological, R. Rui Barbosa, 710 - 44380 - Cruz das Almas, BA - Brazil. *Corresponding author<fmoreira@dcs.ufla.br>

Edited by: Fernando Dini Andreote

Received July 22, 2015

Accepted September 20, 2015
ABSTRACT: Certain nodulating nitrogen-fixing bacteria in legumes and other nodule endophytes perform different plant-growth promoting processes. The objective of this study was to evaluate 26 bacterial strains isolated from cowpea nodules grown in floodplain soils in the Brazilian savannas, regarding performance of plant-growth promoting processes and ability to enhance cowpea growth. We also identified these strains by $16 \mathrm{~S}$ rRNA sequencing. The following processes were evaluated: free-living biological nitrogen fixation (BNF), solubilization of calcium, aluminum and iron phosphates and production of indole-3-acetic acid (IAA). The abilities to nodulate and promote cowpea growth were evaluated in Leonard jars. Partial sequencing of the 16S rRNA gene identified $60 \%$ of the strains as belonging to genus Paenibacillus. The following four genera were also identified: Bacillus, Bradyrhizobium, Enterobacter and Pseudomonas. None of the strains fixed $\mathrm{N}_{2}$ free-living. Among the strains, $80 \%$ solubilized $\mathrm{Ca}$ phosphate and one solubilized Al phosphate and none solubilized Fe phosphate. The highest IAA concentrations $(52.37,51.52$ and $51.00 \mu \mathrm{g} \mathrm{mL} \mathrm{m}^{-1}$ ) were obtained in the 79 medium with tryptophan by Enterobacter strains UFPI B5-7A, UFPI B5-4 and UFPI B5-6, respectively. Only eight strains nodulated cowpea, however, all increased production of total dry matter. The fact that the strains evaluated perform different biological processes to promote plant growth indicates that these strains have potential use in agricultural crops to increase production and environmental sustainability.

Keywords: Paenibacillus, biotechnological potential, biological nitrogen fixation, phosphate solubilization, indole-3-acetic acid

\section{Introduction}

Cowpea [Vigna unguiculata (L.) Walp.] is cultivated in 36 countries and is considered very important in tropical and subtropical regions worldwide, playing a social and economic role for low-income populations. An important cowpea trait is its ability to establish a symbiotic relation with legume-nodulating nitrogen-fixing bacteria (LNNFB). These bacteria can greatly benefit the biological nitrogen fixation (BNF) process of cowpea when they are inoculated with selected strains (Martins et al., 2003; Ferreira et al., 2013; Soares et al., 2014). However, positive responses to inoculation in this crop are not always observed (Rufini et al., 2013), as the edaphoclimatic conditions are very diverse and may hinder the ability of the inoculant strains to survive and compete with native populations, compromising its symbiotic efficiency. Additionally, cowpea is a promiscuous legume species (Guimarães et al., 2012; Jaramillo et al., 2013; Soares et al., 2014), which may compromise the establishment of symbiosis with the inoculant strains.

In studies related to LNNFB diversity and/or selection, coexistence of non-symbiotic endophytic bacteria in surface-sterilized legume nodules has been reported, frequently occurring in the following genera: Agrobacterium, Enterobacter, Pantoea, Bacillus and Paenibacillus (Kan et al., 2007; Li et al., 2008; Lima et al., 2009; Shiraishi et al., 2010; Marra et al., 2012). These non-symbiotic endophytic nodule bacteria, similar to some LN-
$\mathrm{NFB}$, can act on plant nutrition and growth by different mechanisms, such as siderophore production, free-living $\mathrm{N}_{2}$ fixation, phytohormone synthesis and solubilization of inorganic phosphates (Carson et al., 1992; Li et al., 2008; Marra et al., 2012; Oliveira-Longatti et al., 2014). Besides, these bacteria can be considered plant growthpromoting rhizobacteria (PGPR).

In addition to elucidating action mechanisms and potential of plant growth promotion by symbiotic and non-symbiotic bacteria, it is important to identify these bacteria aiming to explore them as biological fertilizers for crops of agricultural interest. Thus, the present study aimed to evaluate 26 bacterial strains isolated from cowpea nodules grown in floodplain soils of the Brazilian savannas in terms of performance of plant-growth promoting processes and ability to enhance cowpea growth, under axenic conditions. We also identified the strains by $16 \mathrm{~S}$ rRNA sequencing.

\section{Materials and Methods}

\section{Origin of strains}

The 26 strains used in this study were isolated from nodules of cowpea (BR 17 Gurguéia cultivar) grown in pots containing soil samples collected from floodplain soils of the Brazilian savannas without any history of inoculant use, in Bom Jesus, Piauí State $\left(09^{\circ} 04^{\prime} 28^{\prime \prime} \mathrm{S}\right.$ and $44^{\circ} 21^{\prime} 31^{\prime \prime} \mathrm{W}$, altitude $\left.277 \mathrm{~m}\right)$, northeastern Brazil. Culture characteristics of these strains are presented in Table 1. 
Table 1 - Identification of symbiotic and non-symbiotic strains isolated from nodules of cowpea grown in floodplain soils based on the most similar sequences found in GenBank (NCBI).

\begin{tabular}{|c|c|c|c|c|c|c|c|}
\hline \multirow{2}{*}{ Strains } & \multicolumn{3}{|c|}{ Growth characteristics in 79 medium ${ }^{\mathrm{a}}$} & \multirow{2}{*}{$\begin{array}{c}\text { NBP } \\
-\end{array}$} & \multicolumn{3}{|c|}{ Most similar sequences found in GenBank (NCBI) } \\
\hline & G.T & $\mathrm{pH}$ & Colony color & & Species & $\%$ S.I & Accession number \\
\hline UFPI B1-5 & Fast & Acid & Yellow & 785 & Paenibacillus sp. & 99 & KF738122.1 \\
\hline UFPI B1-7 & Fast & Neutral & Yellow & 1063 & Bacillus sp. & 99 & HF584765.1 \\
\hline UFPI B1-8 & Fast & Neutral & Cream & 950 & Bacillus sp. & 99 & KC883975.1 \\
\hline UFPI B1-9 & Fast & Neutral & Yellow & 906 & Bacillus sp. & 99 & KF381356.1 \\
\hline UFPI B3-1 & Fast & Neutral & Cream & 889 & Bacillus sp. & 100 & KC189946.1 \\
\hline UFPI B3-3 & Fast & Neutral & Cream & 927 & Bacillus sp. & 100 & KC189946.1 \\
\hline UFPI B3-4 & Slow & Alkaline & Cream & 527 & Bradyrhizobium sp. & 100 & KF738123.1 \\
\hline UFPI B3-5 & Fast & Acid & Yellow & 511 & Paenibacillus sp. & 99 & GU328695.1 \\
\hline UFPI B3-7 & Fast & Acid & Yellow & 948 & Paenibacillus sp. & 99 & GU328695.1 \\
\hline UFPI B4-3 & Fast & Acid & Yellow & 1011 & Paenibacillus sp. & 99 & GU328695.1 \\
\hline UFPI B4-5 & Fast & Acid & Yellow & 567 & Paenibacillus sp. & 99 & GU328695.1 \\
\hline UFPI B4-6 & Fast & Acid & Yellow & 1080 & Paenibacillus sp. & 99 & GU328695.1 \\
\hline UFPI B4-7 & Fast & Acid & Yellow & 921 & Paenibacillus sp. & 100 & JN084141.1 \\
\hline UFPI B5-4 & Fast & Acid & Yellow & 892 & Enterobacter sp. & 100 & KF738121.1 \\
\hline UFPI B5-6 & Fast & Acid & Yellow & 945 & Enterobacter sp. & 99 & AY335554.1 \\
\hline UFPI B5-7A & Fast & Acid & Yellow & 819 & Enterobacter sp. & 99 & HE646630.1 \\
\hline UFPI B5-8A & Fast & Alkaline & Cream & 723 & Pseudomonas sp. & 99 & JQ247014.1 \\
\hline UFPI B6-1 & Fast & Acid & Cream & 865 & Paenibacillus sp. & 100 & KC434972.1 \\
\hline UFPI B6-3 & Fast & Acid & Cream & 913 & Paenibacillus sp. & 100 & KC434972.1 \\
\hline UFPI B6-9B & Fast & Acid & Cream & 880 & Paenibacillus sp. & 100 & KC434972.1 \\
\hline UFPI B7-3 & Fast & Acid & Yellow & 814 & Paenibacillus sp. & 100 & KC434972.1 \\
\hline UFPI B7-5 & Fast & Acid & Yellow & 932 & Paenibacillus sp. & 100 & JN084141.1 \\
\hline UFPI B7-6 & Fast & Acid & Yellow & 974 & Paenibacillus sp. & 99 & GU328679.1 \\
\hline UFPI B7-7B & Fast & Acid & Yellow & 453 & Paenibacillus sp. & 99 & KF738129.1 \\
\hline UFPI B7-8 & Fast & Acid & Yellow & 952 & Paenibacillus sp. & 99 & KF738122.1 \\
\hline UFPI B7-9 & Fast & Acid & Yellow & 981 & Paenibacillus sp. & 99 & GU328679.1 \\
\hline
\end{tabular}

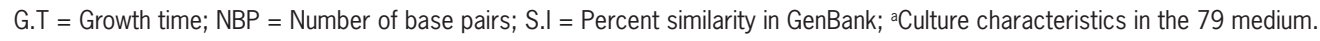

\section{Genetic identification of strains}

DNA was extracted from the strains using the bacterial genomic DNA extraction kit (ZR Fungal/Bacterial DNA MiniPrepTM, Zymo Research) after the bacteria growth in 79 liquid medium (Fred and Waksman, 1928) at $28{ }^{\circ} \mathrm{C}$. The $16 \mathrm{~S}$ rRNA gene was partially amplified with final reaction volume of $50 \mu \mathrm{L}$. The following concentrations were used: $5 \mu \mathrm{L}$ DNA, $5 \mu \mathrm{L}$ dNTP $(2 \mathrm{mM})$, $5 \mu \mathrm{L} \mathrm{10x}$ buffer, $4 \mu \mathrm{L} \mathrm{MgCl}_{2}(25 \mathrm{mM}), 1 \mu \mathrm{L}$ of each primer $(10 \mu \mathrm{M}), 27 \mathrm{~F}$ primer (5'-AGAGTTTGATCCTGGCTCAG-3') and 1492R primer (5'-GGTTACCTTGTTACGACTT-3') (Lane, 1991), $0.4 \mu \mathrm{L}$ Taq DNA polymerase

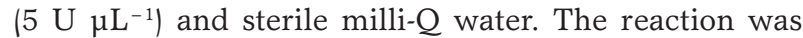
performed in Mastercycler Eppendorf tubes (Germany) using the following cycles: initial denaturation $194{ }^{\circ} \mathrm{C}$ for $5 \mathrm{~min}), 35$ cycles of denaturation $\left(94^{\circ} \mathrm{C}\right.$ for $\left.40 \mathrm{~s}\right)$, annealing $\left(55^{\circ} \mathrm{C}\right.$ for $\left.40 \mathrm{~s}\right)$, extension $\left(72^{\circ} \mathrm{C}\right.$ for $\left.1.5 \mathrm{~min}\right)$ and final extension $\left(72{ }^{\circ} \mathrm{C}\right.$ for $\left.7 \mathrm{~min}\right)$. PCR products were sent to the Macrogen Laboratory (Korea) for purification and sequencing, performed in oligonucleotide primer $27 \mathrm{~F}$. The sequence quality was evaluated using the BioNumerics (version 7.1) program. Additionally, sequences were subjected to BLASTn for comparison with similar sequences deposited in the GenBank database
(National Center for Biotechnology Information - NCBI) (http://www.ncbi.nlm.nih.gov) and placed under accession numbers KJ879598 to KJ879623.

\section{Free-living nitrogen fixation}

To evaluate the free-living $\mathrm{N}_{2}$-fixing ability, strains and positive control BR $5401^{\mathrm{T}}$ (Azorhizobium doebereinerae) (Moreira et al., 2006) were inoculated into flasks containing $10 \mathrm{~mL}$ of semi-solid $\mathrm{N}$-free culture medium - LO (Dreyfus et al., 1983). Mannitol was also tested as a C source, replacing lactate. The flasks were incubated for 7 day in the dark at $28{ }^{\circ} \mathrm{C}$ and the strains were compared with the positive control (BR $5401^{\mathrm{T}}$ ) to observe the formation of a pellicle near the LO medium surface.

\section{Solubilization of $\mathrm{Ca}, \mathrm{Al}$ and $\mathrm{Fe}$ inorganic phos- phates}

The strains were evaluated regarding the ability to solubilize the following insoluble inorganic phosphate sources: $\mathrm{CaHPO}_{4}, \mathrm{AlH}_{6} \mathrm{O}_{12} \mathrm{P}_{3}$ and $\mathrm{FePO}_{4} \cdot 2 \mathrm{H}_{2} \mathrm{O}$. For solubilization of $\mathrm{CaHPO}_{4}$, the NBRIP solid medium (Nautiyal, 1999) was used. The ability to solubilize $\mathrm{AlH}_{6} \mathrm{O}_{12} \mathrm{P}_{3}$ was evaluated in the GES solid medium containing $\left(\mathrm{L}^{-1}\right)$ : $10 \mathrm{~g}$ glucose, $100 \mathrm{~mL}$ soil extract, $2 \mathrm{~mL} \mathrm{MgSO}_{4}(10 \%)$, 
$2 \mathrm{~mL} \mathrm{CaCl}_{2}(1 \%), 1 \mathrm{~mL} \mathrm{NaCl}, 2 \mathrm{~mL}$ micronutrient solution $\left(0.2 \mathrm{~g} \mathrm{Ca}_{2} \mathrm{MoO}_{4} \cdot 2 \mathrm{H}_{2} \mathrm{O}, 0.235 \mathrm{~g} \mathrm{MnSO}_{4} \cdot \mathrm{H}_{2} \mathrm{O}, 0.28 \mathrm{~g}\right.$ $\mathrm{H}_{3} \mathrm{BO}_{3}, 0.008 \mathrm{~g} \mathrm{CuSO}_{4} .5 \mathrm{H}_{2} \mathrm{O}$ and $0.024 \mathrm{~g} \mathrm{ZnSO} \cdot 7 \mathrm{H}_{2} \mathrm{O}$ dissolved in $200 \mathrm{~mL}$ of distilled water), $4 \mathrm{~mL} \mathrm{Fe-EDTA}$ (1.64 \%), $0.1 \mathrm{~g} \mathrm{KNO}_{3}, 3.04 \mathrm{~g} \mathrm{AlH}_{6} \mathrm{O}_{12} \mathrm{P}_{3}$ and $20 \mathrm{~g}$ agar. The $\mathrm{pH}$ was adjusted to 4.5. To evaluate the solubilizing ability of $\mathrm{FePO}_{4} \cdot 2 \mathrm{H}_{2} \mathrm{O}$, the GELP solid medium was used containing $\left(\mathrm{L}^{-1}\right)$ : $10 \mathrm{~g}$ glucose, $0.05 \mathrm{~g}$ yeast extract, $5 \mathrm{~g}$ bacteriological peptone, $100 \mathrm{~mL}$ soil extract, $0.2 \mathrm{~g}$ $\mathrm{MgSO}_{4}, 0.02 \mathrm{~g} \mathrm{CaCl}_{2}, 0.1 \mathrm{~g} \mathrm{NaCl}, 0.1 \mathrm{~g} \mathrm{KNO}_{3}, 4 \mathrm{~mL} \mathrm{Fe}-$ EDTA, $0.89 \mathrm{~g} \mathrm{FePO}_{4} \cdot 2 \mathrm{H}_{2} \mathrm{O}, 2 \mathrm{~mL}$ micronutrient solution and $15 \mathrm{~g}$ agar. The $\mathrm{pH}$ was adjusted to 7.0. The strain UFLA 03-09 (Acinetobacter sp.) was used as a positive control for solubilization of $\mathrm{CaHPO}_{4}$ (Marra et al., 2012).

To obtain the inocula, strains were cultured in the 79 liquid medium without bromothymol blue dye, under shake at $110 \mathrm{rpm}$ at $28{ }^{\circ} \mathrm{C}$. Next, the optical density was adjusted $(0.5)$ by adding saline solution $(0.85 \% \mathrm{NaCl})$ and $20 \mu \mathrm{L}$ of the cell suspensions was applied separately (in four equidistant points) to Petri dishes $19.5 \mathrm{~cm} \mathrm{di}$ ameter) already separately containing the media with phosphate precipitates. Every three days, the diameter of the solubilization zone (translucent area surrounding the colony) and of the colony corresponding to the zone were measured for 15 days. Based on these measurements, the solubilization indices were obtained (SIs) = $\varnothing$ zone $(\mathrm{mm}) / \varnothing$ colony $(\mathrm{mm})$ (Berraquero et al., 1976). Based on the SIs, strains were classified as having low (SI $<2 \mathrm{~mm})$, medium $(2 \geq \mathrm{SI}<4.0 \mathrm{~mm})$ or high $(\mathrm{SI}>4 \mathrm{~mm})$ solubilization ability. Starting at the onset of solubilization, strains were also classified as early (solubilization onset until the $3^{\text {rd }}$ day), late (solubilization onset after the $3^{\text {rd }}$ day) or non-solubilizing (no visible solubilization until the $15^{\text {th }}$ day of evaluation).

\section{Auxin production (indole-3-acetic acid - IAA)}

To evaluate the ability to synthesize IAA, strains and the positive control BR $11001^{\mathrm{T}}$ (Azospirillum brasilense) (Radwan et al., 2002) were initially inoculated in the 79 medium (Fred and Waksman, 1928), without bromothymol blue dye and in DYGS medium, containing $\left(\mathrm{L}^{-1}\right): 2.0 \mathrm{~g}$ glucose, $2.0 \mathrm{~g}$ malic acid, $1.5 \mathrm{~g}$ bacteriological peptone, $2.0 \mathrm{~g}$ yeast extract, $0.5 \mathrm{~g} \mathrm{~K}_{2} \mathrm{HPO}_{4}, 0.5 \mathrm{~g}$ $\mathrm{MgSO}_{4} .7 \mathrm{H}_{2} \mathrm{O}, 1.5 \mathrm{~g}$ glutamic acid and $\mathrm{pH}$ adjusted to 6.5 . After growth, the optical density was adjusted (0.5) by adding saline solution $(0.85 \% \mathrm{NaCl})$ and $500 \mu \mathrm{L}$ aliquots of a bacterial solution of each strain were inoculated in triplicate into flasks containing $20 \mathrm{~mL}$ of the respective medium into which the bacteria were initially inoculated (79 or DYGS), supplemented with $100 \mathrm{mg} \mathrm{L}^{-1}$ of tryptophan and without tryptophan supplementation. The strains were incubated at $28^{\circ} \mathrm{C}$ under $110 \mathrm{rpm}$ shake. After growth, cells were centrifuged at 17,792 g for 10 min. Next, $3 \mathrm{~mL}$ of the supernatant was removed and $2 \mathrm{~mL}$ of Salkowski reagent (Sarwar and Kremer, 1995) was added. The material was kept in the dark for $30 \mathrm{~min}$ to allow development of the pink color, indicating IAA production. Color intensity was determined in a spec- trophotometer at $535 \mathrm{~nm}$ (Asghar et al., 2002). IAA concentration was estimated using a standard curve previously obtained with the sterilized culture media (79 and DYGS) and known quantities of IAA (0 to $100 \mu \mathrm{g} \mathrm{mL}^{-1}$ ).

The experiments (in absence and presence of tryptophan supplementation) followed a completely randomized design with three replicates and were arranged in a factorial design. In each experiment, the ability of IAA production of strains and the positive control (BR $11001^{\mathrm{T}}$ ) were evaluated, composing the following factorial: 27 (strains) $\times 2$ (culture media, 79 and DYGS). The data from each trial were subjected to the analysis of variance, using the statistical analysis program Sisvar, version 5.3 (Ferreira, 2011). The effects of the treatments were compared by the Scott-Knott test, at $5 \%$ probability.

\section{Evaluating strains efficiency in promoting cowpea growth}

Between June and August 2012, an experiment was performed in the greenhouse to evaluate the symbiotic efficiency and/or strains ability to promote cowpea growth (BR 17 Gurguéia cultivar) in Leonard jars (Vincent, 1970). In this experiment, 26 strains, three positive controls comprising inoculations with Bradyrhizobium strains authorized by MAPA (Ministério da Agricultura Pecuária e Abastecimento - Brazilian Ministry of Livestock Agriculture and Supply) as inoculants for cowpea (INPA 03-11B, UFLA 03-84 and BR 3267) and two uninoculated negative controls, one with low mineral $\mathrm{N}$ concentration (LN) and another with high mineral $\mathrm{N}$ concentration $(\mathrm{HN})$, were evaluated. The experiment followed a completely randomized design with three replicates.

A mixture of sand and vermiculite $1: 2(\mathrm{v} / \mathrm{v})$ was added to the top portion of the Leonard jars and Hoagland nutritional solution was added to the lower portion (Hoagland and Arnon, 1950). In the inoculated treatments and in the control without inoculation with low mineral $\mathrm{N}$ concentration, $5.25 \mathrm{mg} \mathrm{L}^{-1}$ of $\mathrm{N}$ was used. In the control without inoculation with high mineral $\mathrm{N}$ concentration, $52.5 \mathrm{mg} \mathrm{L}^{-1}$ of $\mathrm{N}$ was used in the nutritional solution. $\mathrm{Ca}\left(\mathrm{NO}_{3}\right)_{2} \cdot 4 \mathrm{H}_{2} \mathrm{O} ; \mathrm{KNO}_{3}$ and $\mathrm{NH}_{4} \mathrm{H}_{2} \mathrm{PO}_{4}$ were used as $\mathrm{N}$ sources in the nutrition solution. After preparing the jars and the nutritional solution, they were autoclaved for $1 \mathrm{~h}$ under $1.5 \mathrm{~kg} \mathrm{~cm}^{-2}$ pressure at $121^{\circ} \mathrm{C}$.

Before sowing, cowpea seeds were surface-sterilized using $98 \%$ ethyl alcohol (30 s) and $2 \% \mathrm{Na}$ hypochlorite $(2 \mathrm{~min})$ and then were subjected to successive washings in sterile distilled water. Four pre-germinated seeds were planted in each jar. In each treatment with inoculation, $1 \mathrm{~mL}$ of the inoculant at concentration of 1 $\times 10^{8}$ bacterial cells $\mathrm{mL}^{-1}$ was added to the top of each pre-germinated seed. After sowing and inoculating, the jars were covered with a layer of paraffin sand $(10 \mathrm{~kg}$ of sand, $1 \mathrm{~L}$ of chloroform and $10 \mathrm{~g}$ of paraffin) to avoid possible contamination. The plants were thinned on the $5^{\text {th }}$ day after emergence, leaving two plants per jar. 
During the experiment, the nutritional solution was prepared, autoclaved and reapplied to the jars periodically.

At 60 days after sowing, at flowering, the plants were collected to determine the nodules number (NN), the nodules dry matter (NDM), shoots dry matter (SDM), roots dry matter (RDM) and total dry matter (TDM), the efficiency compared to the uninoculated control with a high concentration of mineral $\mathrm{N}(\mathrm{EFN})$ and shoot $\mathrm{N}$ accumulation (SNA). To determine NDM, SDM and RDM, the nodules, shoots and roots were placed in paper bags and dried in an air-circulated oven at $60{ }^{\circ} \mathrm{C}$ until reaching a constant matter. The EFN was calculated using the following formula: $\mathrm{EFN}=(\mathrm{SDM}$ treatment*100)/(SDM of the treatment with high concentration of mineral N). The SNA was calculated by multiplying the SDM (mg) by the $\mathrm{N}$ content $(\%) / 100$. The $\mathrm{N}$ content in the shoots was determined by the semimicro-Kjeldahl method.

\section{Statistical Analysis}

The data were subjected to the analysis of variance, using the statistical analysis program Sisvar, version 5.3 (Ferreira, 2011). The effects of the treatments were compared by the Scott-Knott test at $5 \%$ probability. The NN and DMN data were transformed to the square root of $(\mathrm{Y}+0.5)$.

\section{Results}

\section{Genetic identification of the strains}

A comparison of partial sequences of the $16 \mathrm{~S}$ rRNA gene of the strains evaluated with sequences deposited in GenBank showed that most of the strains (60 $\%)$ belonged to genus Paenibacillus (Table 1). Four other genera were also identified: Bacillus (UFPI B1-7, UFPI B1-8, UFPI B1-9, UFPI B3-1 and UFPI B3-3), Bradyrhizobium (UFPI B3-4), Enterobacter (UFPI B5-4, UFPI B5-6 and UFPI B5-7A) and Pseudomonas (UFPI B5-8A).

\section{Free-living $\mathbf{N}$ fixation}

None of the 26 strains formed a pellicle near the LO medium surface, regardless of the $\mathrm{C}$ source used $(\mathrm{Na}$ lactate or mannitol). The positive control BR $5401^{\mathrm{T}}$ (Azorhizobium doebereinerae) formed a film only when $\mathrm{Na}$ lactate was used as $\mathrm{C}$ source, indicating adequate conditions of the culture medium for free-living $\mathrm{N}_{2}$ fixation (data not shown).

\section{Solubilization of $\mathrm{Ca}, \mathrm{Al}$ and $\mathrm{Fe}$ inorganic phos- phates}

Most strains (80\%), including representatives of four genera (Bacillus, Enterobacter, Paenibacillus and Pseudomonas), were able to solubilize Ca phosphate (Table 2). Among the strains that solubilized this phosphate, UFPI B5-6 (Enterobacter sp.) and UFPI B5-8A (Pseudomonas) promoted the highest final solubilization indices (3.54 and 2.32, respectively), close to the index (2.44) obtained with the positive control UFLA 03-09 (Acinetobacter sp.). No strain promoted a high solubilization index. According to the solubilization onset, 11 strains began solubilization until the $3^{\text {rd }}$ day after inoculation and thus, were considered early. Only strain UFPI B5-4 (Enterobacter sp.) was able to solubilize $\mathrm{Al}$ phosphate; however, this strain promoted a low index and was considered late. None of the strains was able to solubilize Fe phosphate, despite the fact that all were grown in the medium containing this phosphate (Table 2).

\section{Auxin production (indole-3-acetic acid - IAA)}

There was interaction ( $p \leq 0.05)$ between the strains and the culture media (79 and DYGS) in the evaluations performed in presence and absence of tryptophan supplementation (Table 3). In DYGS medium without tryptophan, seven strains belonging to different genera Enterobacter (UFPI B5-4, UFPI B5-6 and UFPI B57A), Pseudomonas (UFPI B5-8A) and Paenibacillus (UFPI B4-3, UFPI B6-1 and UFPI B6-3) and the positive control BR $11001^{\mathrm{T}}$ (Azospirillum brasilense) synthesized IAA. Concentrations in this medium ranged from 0.40 to 9.58 $\mu \mathrm{g} \mathrm{mL} \mathrm{m}^{-1}$ obtained with strains UFPI B6-1 and UFPI B5$7 \mathrm{~A}$, respectively. In the 79 medium without tryptophan, only BR $11001^{\mathrm{T}}$ synthesized IAA; however, it produced lower $(p \leq 0.05)$ quantity than when inoculated in the DYGS medium (Table 3).

In presence of tryptophan supplementation, 18 strains were able to synthesize IAA in the 79 medium, among which, 16 strains promoted higher $(p \leq 0.05)$ quantities than in the DYGS medium inoculated with these strains (Table 3). Among the strains inoculated in the 79 medium with tryptophan, the highest IAA concentrations (52.37, 51.52 and $51.00 \mu \mathrm{g} \mathrm{mL}^{-1}$ ) were obtained with strains belonging to genus Enterobacter (UFPI B5-7A, UFPI B5-4 and UFPI B5-6, respectively). In the DYGS medium with tryptophan, six strains, UFPI B3-4 (Bradyrhizobium sp.), UFPI B5-8A (Pseudomonas sp.), UFPI B6-3, UFPI B7-5, UFPI B7-6, UFPI B7-8 (Paenibacillus sp.) and BR $11001^{\mathrm{T}}$ (Azospirillum brasilense) synthesized higher $(p \leq 0.05)$ quantities of IAA compared to the 79 medium inoculated with these strains (Table 3). Among the strains inoculated in the DYGS medium with tryptophan, Enterobacter strains (UFPI B5-6, UFPI B5-7A and UFPI B5-4) synthesized the highest ( $p \leq 0.05)$ IAA concentrations $(26.54,25.85$ and 14.75 , respectively) (Table 3).

Efficiency of strains in promoting cowpea plant growth In the experiment conducted in Leonard jars with cowpea, the treatments affected $(p \leq 0.05)$ all of variables evaluated (Table 4). There was no nodulation in the uninoculated controls, indicating no contamination in the experiment. Among the strains evaluated, only eight were able to nodulate cowpea, six belonging to genus Paenibacillus (UFPI B3-5, UFPI B3-7, UFPI B4-3, UFPI B4-5, UFPI B4-6 and UFPI B7-6), one to genus Enterobacter (UFPI B5-7A) and another to genus Bradyrhizobium (UFPI B3-4). The mean NN values among these strains ranged from 56 to 165 nodules per plant obtained, re- 


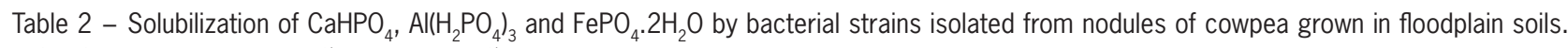
S.I, Solubilization index $=\varnothing$ zone $(\mathrm{mm}) / \varnothing$ colony $(\mathrm{mm})$.

\begin{tabular}{|c|c|c|c|c|c|c|c|}
\hline \multirow{3}{*}{ Strains } & \multicolumn{3}{|c|}{$\mathrm{CaHPO}_{4}$} & \multicolumn{3}{|c|}{$\mathrm{Al}\left(\mathrm{H}_{2} \mathrm{PO}_{4}\right)_{3}$} & \multirow{3}{*}{$\begin{array}{c}\mathrm{FePO}_{4} \cdot 2 \mathrm{H}_{2} \mathrm{O} \\
\mathrm{S} . \mathrm{I} \\
-\end{array}$} \\
\hline & \multicolumn{2}{|c|}{ S.I } & \multirow{2}{*}{$\begin{array}{c}\text { Sol. ab. } \\
-\end{array}$} & \multicolumn{2}{|c|}{ S.I } & \multirow{2}{*}{$\begin{array}{c}\text { Sol. ab. }{ }^{b} \\
-\end{array}$} & \\
\hline & Initial (Days) ${ }^{a}$ & End & & Initial (Days) & End & & \\
\hline \multicolumn{8}{|l|}{ Bacillus sp. } \\
\hline UFPI B1-7 & $1.18(3)$ & 1.24 & Low & $N G$ & $N G$ & - & GNS \\
\hline UFPI B1-8 & $1.26(3)$ & 1.28 & Low & $N G$ & $N G$ & - & GNS \\
\hline UFPI B1-9 & $1.17(3)$ & 1.18 & Low & $N G$ & $N G$ & - & GNS \\
\hline UFPI B3-1 & $1.17(3)$ & 1.18 & Low & $N G$ & $N G$ & - & GNS \\
\hline UFPI B3-3 & $1.17(3)$ & 1.23 & Low & $N G$ & $N G$ & - & GNS \\
\hline \multicolumn{8}{|c|}{ Bradyrhizobium sp. } \\
\hline UFPI B3-4 & GNS & GNS & - & $N G$ & $N G$ & - & GNS \\
\hline \multicolumn{8}{|c|}{ Enterobacter sp. } \\
\hline UFPI B5-4 & $1.44(3)$ & 1.77 & Low & $1.20(12)$ & 1.20 & Low & GNS \\
\hline UFPI B5-6 & $2.16(3)$ & 3.54 & Medium & GNS & GNS & - & GNS \\
\hline UFPI B5-7A & $1.41(3)$ & 1.47 & Low & GNS & GNS & - & GNS \\
\hline \multicolumn{8}{|c|}{ Pseudomonas sp. } \\
\hline UFPI B5-8A & $2.13(3)$ & 2.32 & Medium & $N G$ & $N G$ & - & GNS \\
\hline \multicolumn{8}{|c|}{ Paenibacillus sp. } \\
\hline UFPI B1-5 & $1.24(9)$ & 1.26 & Low & $N G$ & $N G$ & - & GNS \\
\hline UFPI B3-5 & $1.32(6)$ & 1.45 & Low & $N G$ & $N G$ & - & GNS \\
\hline UFPI B3-7 & $1.21(6)$ & 1.33 & Low & $N G$ & $N G$ & - & GNS \\
\hline UFPI B4-3 & $1.27(6)$ & 1.44 & Low & $N G$ & $N G$ & - & GNS \\
\hline UFPI B4-5 & $1.27(3)$ & 1.29 & Low & $N G$ & $N G$ & - & GNS \\
\hline UFPI B4-6 & $1.28(3)$ & 1.43 & Low & $N G$ & $N G$ & $\therefore$ & GNS \\
\hline UFPI B4-7 & $1.37(6)$ & 1.42 & Low & $N G$ & $N G$ & - & GNS \\
\hline UFPI B6-1 & $1.44(6)$ & 1.72 & Low & $N G$ & $N G$ & - & GNS \\
\hline UFPI B6-3 & $1.36(6)$ & 1.37 & Low & $N G$ & $N G$ & - & GNS \\
\hline UFPI B6-9B & GNS & GNS & - & $N G$ & $N G$ & - & GNS \\
\hline UFPI B7-3 & $1.27(6)$ & 1.31 & Low & $N G$ & $N G$ & - & GNS \\
\hline UFPI B7-5 & GNS & GNS & - & $\mathrm{NG}$ & $N G$ & - & GNS \\
\hline UFPI B7-6 & $1.28(9)$ & 1.30 & Low & $N G$ & $N G$ & - & GNS \\
\hline UFPI B7-7B & $1.19(6)$ & 1.21 & Low & GNS & GNS & - & GNS \\
\hline UFPI B7-8 & GNS & GNS & - & GNS & GNS & - & GNS \\
\hline UFPI B7-9 & GNS & GNS & - & $N G$ & $N G$ & - & GNS \\
\hline \multicolumn{8}{|c|}{ Acinetobacter sp. ${ }^{\mathrm{c}}$} \\
\hline UFLA03 09 & $2.08(3)$ & 2.44 & Medium & $N G$ & $N G$ & - & GNS \\
\hline
\end{tabular}

spectively, in the treatments inoculated with strains UFPI B7-6 and UFPI B3-4. Higher ( $p \leq 0.05)$ mean NN (226 nodules per plant) and NDM (237 mg per plant) values were obtained with the inoculant strain INPA 03$11 \mathrm{~B}$, which differed $(p \leq 0.05)$ from the other treatments. The treatments inoculated with strains UFPI B3-4 UFPI B5-7A, UFPI B3-5, UFPI B4-3 and UFPI B4-5 showed $\mathrm{NN}$ values higher $(p \leq 0.05)$ than two of the inoculant strains (UFLA 03-84 and BR 3267). Strain UFPI B3-4 promoted higher $(p \leq 0.05)$ NDM than inoculant strains UFLA 03-84 and BR 3267 and the other strains evaluated, except for INPA 03-11B. NDM values of strains UFPI B3-5, UFPI B4-3 and UFPI B5-7A and of the inoculant strains UFLA 03-84 and BR 3267 were similar (Table 4).

Regarding SDM, the treatment inoculated with INPA 03-11B also showed a mean production (3620 mg per plant) higher ( $p \leq 0.05)$ than the other treatments, including the control with high mineral $\mathrm{N}$ concentration (3195 mg per plant) (Table 4). All other strains showed a production lower $(p \leq 0.05)$ than the control with high mineral N concentration. Strain UFLA 03-84, despite promoting lower SDM than INPA 03-11B and the control with high mineral $\mathrm{N}$ concentration, presented higher performance than the other strains. Among the strains evaluated, UFPI B3-4 was the only one that promoted a mean of SDM production similar $(p \leq 0.05)$ to that of the inoculant strains (BR 3267). However, compared to the control with low mineral $\mathrm{N}$ concentration, $73 \%$ of the strains promoted higher $(p \leq 0.05)$ SDM production (Table 4).

Production of RDM and TDM ranged from 126 to 2103 and 324 to 5298 mg per plant obtained in the con- 
Table 3 - Production of indole-3-acetic acid (IAA) by bacterial strains isolated from nodules of cowpea grown in floodplain soils, cultured in the 79 and DYGS media without and with addition of tryptophan.

\begin{tabular}{|c|c|c|c|c|}
\hline \multirow[t]{2}{*}{ Strains } & \multicolumn{2}{|c|}{$\begin{array}{l}\text { Without tryptophan } \\
\left(\mu \mathrm{g} \mathrm{mL} \mathrm{m}^{-1}\right)\end{array}$} & \multicolumn{2}{|c|}{$\begin{array}{l}\text { With } 100 \mathrm{mg} \mathrm{L}^{-1} \text { tryptophan } \\
\left(\mu \mathrm{g} \mathrm{mL}^{-1}\right)\end{array}$} \\
\hline & 79 medium & DYGS medium & 79 medium & DYGS medium \\
\hline \multicolumn{5}{|l|}{ Bacillus sp. } \\
\hline UFPI B1-7 & $0.00 \mathrm{bA}$ & $0.00 \mathrm{gA}$ & $5.94 \mathrm{gA}$ & $0.00 \mathrm{jB}$ \\
\hline UFPI B1-8 & $0.00 \mathrm{bA}$ & $0.00 \mathrm{gA}$ & $11.82 \mathrm{dA}$ & $0.00 \mathrm{jB}$ \\
\hline UFPI B1-9 & $0.00 \mathrm{bA}$ & $0.00 \mathrm{gA}$ & $6.58 \mathrm{fA}$ & $0.00 \mathrm{jB}$ \\
\hline UFPI B3-1 & $0.00 \mathrm{bA}$ & $0.00 \mathrm{gA}$ & $3.71 \mathrm{iA}$ & $0.05 \mathrm{jB}$ \\
\hline UFPI B3-3 & $0.00 \mathrm{bA}$ & $0.00 \mathrm{gA}$ & $0.00 \mathrm{rA}$ & $0.00 \mathrm{jA}$ \\
\hline \multicolumn{5}{|c|}{ Bradyrhizobium sp. } \\
\hline UFPI B3-4 & $0.00 \mathrm{bA}$ & $0.00 \mathrm{gA}$ & $0.00 \mathrm{rB}$ & $1.07 \mathrm{gA}$ \\
\hline \multicolumn{5}{|c|}{ Enterobacter sp. } \\
\hline UFPI B5-4 & $0.00 \mathrm{bB}$ & $6.10 \mathrm{bA}$ & $51.52 \mathrm{bA}$ & $14.75 \mathrm{cB}$ \\
\hline UFPI B5-6 & $0.00 \mathrm{bB}$ & $2.87 \mathrm{dA}$ & $51.00 \mathrm{cA}$ & $26.54 \mathrm{aB}$ \\
\hline UFPI B5-7A & $0.00 \mathrm{bB}$ & $9.58 \mathrm{aA}$ & $52.37 \mathrm{aA}$ & $25.85 \mathrm{bB}$ \\
\hline \multicolumn{5}{|c|}{ Pseudomonas sp. } \\
\hline UFPI B5-8A & $0.00 \mathrm{bB}$ & $5.40 \mathrm{cA}$ & $1.86 \mathrm{IB}$ & $9.71 \mathrm{eA}$ \\
\hline \multicolumn{5}{|c|}{ Paenibacillus sp. } \\
\hline UFPI B1-5 & $0.00 \mathrm{bA}$ & $0.00 \mathrm{gA}$ & $0.00 \mathrm{rA}$ & $0.00 \mathrm{jA}$ \\
\hline UFPI B3-5 & $0.00 \mathrm{bA}$ & $0.00 \mathrm{gA}$ & $0.62 \mathrm{pA}$ & $0.00 \mathrm{jB}$ \\
\hline UFPI B3-7 & $0.00 \mathrm{bA}$ & $0.00 \mathrm{gA}$ & $0.41 \mathrm{qA}$ & $0.00 \mathrm{jB}$ \\
\hline UFPI B4-3 & $0.00 \mathrm{bB}$ & $2.57 \mathrm{eA}$ & $11.33 \mathrm{eA}$ & $3.15 \mathrm{fB}$ \\
\hline UFPI B4-5 & $0.00 \mathrm{bA}$ & $0.00 \mathrm{gA}$ & $0.00 \mathrm{rA}$ & $0.00 \mathrm{jA}$ \\
\hline UFPI B4-6 & $0.00 \mathrm{bA}$ & $0.00 \mathrm{gA}$ & $2.92 \mathrm{jA}$ & $0.00 \mathrm{jB}$ \\
\hline UFPI B4-7 & $0.00 \mathrm{bA}$ & $0.00 \mathrm{gA}$ & $1.52 \mathrm{~mA}$ & $0.00 \mathrm{jB}$ \\
\hline UFPI B6-1 & $0.00 \mathrm{bB}$ & $0.40 \mathrm{fA}$ & $1.29 \mathrm{nA}$ & $0.54 \mathrm{hB}$ \\
\hline UFPI B6-3 & $0.00 \mathrm{bB}$ & $1.14 \mathrm{eA}$ & $0.00 \mathrm{rB}$ & $0.38 \mathrm{iA}$ \\
\hline UFPI B6-9B & $0.00 \mathrm{bA}$ & $0.00 \mathrm{gA}$ & $0.92 \mathrm{aA}$ & $0.00 \mathrm{jB}$ \\
\hline UFPI B7-3 & $0.00 \mathrm{bA}$ & $0.00 \mathrm{gA}$ & $11.27 \mathrm{eA}$ & $0.00 \mathrm{jB}$ \\
\hline UFPI B7-5 & $0.00 \mathrm{bA}$ & $0.00 \mathrm{gA}$ & $0.00 \mathrm{rB}$ & $0.84 \mathrm{gA}$ \\
\hline UFPI B7-6 & $0.00 \mathrm{bA}$ & $0.00 \mathrm{gA}$ & $0.09 \mathrm{rB}$ & $0.87 \mathrm{gA}$ \\
\hline UFPI B7-7B & $0.00 \mathrm{bA}$ & $0.00 \mathrm{gA}$ & $6.54 \mathrm{fA}$ & $0.61 \mathrm{hB}$ \\
\hline UFPI B7-8 & $0.00 \mathrm{bA}$ & $0.00 \mathrm{gA}$ & $0.00 \mathrm{rB}$ & $0.87 \mathrm{gA}$ \\
\hline UFPI B7-9 & $0.00 \mathrm{bA}$ & $0.00 \mathrm{gA}$ & $0.00 \mathrm{rA}$ & $0.00 \mathrm{jA}$ \\
\hline \multicolumn{5}{|c|}{ Azospirillum brasilense ${ }^{a}$} \\
\hline BR $11001^{\top}$ & $0.82 \mathrm{aB}$ & $6.12 \mathrm{bA}$ & $5.17 \mathrm{hB}$ & $14.33 \mathrm{dA}$ \\
\hline CV (\%) & \multicolumn{2}{|c|}{9.32} & \multicolumn{2}{|c|}{2.42} \\
\hline
\end{tabular}

Means followed by the same letters, lowercase in the columns and uppercase in the rows, are not different at $p \leq 0.05$; apositive control.

trols with low and high mineral $\mathrm{N}$ concentrations, respectively (Table 4). All strains, including the inoculants, promoted a lower production of RDM and TDM than the control with high mineral N concentration. Among the inoculated treatments, strain INPA 03-11B promoted higher $(p \leq 0.05)$ RDM and TDM than the others. Regarding RDM, strain UFPI B3-4 was grouped with strain BR 3267 and promoted higher $(p \leq 0.05)$ production than seven other tested nodulating strains and UFLA 03-84.

For TDM, strain UFLA 03-84 promoted a higher production compared with the other strains, except for INPA 03-11B. Compared to the control with low mineral $\mathrm{N}$ concentration, all strains evaluated showed increased $(p \leq 0.05)$ TDM production. Among the strains that did not nodulate, increases obtained in RDM and TDM compared to the control with low mineral $\mathrm{N}$ concentration were up to 328 and $189 \%$, respectively, in the treatment inoculated with strain UFPI B5-4 (Enterobacter sp.) (Table 4). On the other hand, production of RDM and TDM in relation to the control with high mineral $\mathrm{N}$ concentration was 26 and $18 \%$, respectively, in the treatment inoculated with the same strain.

Regarding SNA, the inoculant strain INPA 03-11B was different from the other treatments and also promoted higher $(p \leq 0.05) \mathrm{N}$ accumulation than the control with high N concentration (Table 4). Strains UFLA 0384 and BR 3267 promoted higher $(p \leq 0.05) \mathrm{N}$ accumulations than the strains evaluated and among the eight nodulating strains, Bradyrhizobium strain (UFPI B3-4) was different $(p \leq 0.05)$ from the others. Paenibacillus strains (UFPI B3-7, UFPI B4-6 and UFPI B7-6) were entirely inefficient in $\mathrm{BNF}$, as SNA values of treatments 
Table 4 - Effect of inoculation with strains isolated from floodplain soils on cowpea plant growth under greenhouse conditions. NN = nodules number; $\mathrm{NDM}=$ nodules dry matter; $\mathrm{SDM}=$ shoots dry matter; RDM = roots dry matter; TDM = total dry matter; SNA = shoots nitrogen accumulation; EFN = efficiency compared to the control with high nitrogen concentration.

\begin{tabular}{|c|c|c|c|c|c|c|c|}
\hline Treatments & NN & NDM & SDM & RDM & TDM & SNA & EFN \\
\hline & - & & 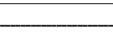 & gg per plan & 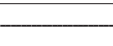 & 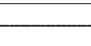 & $\%$ \\
\hline \multicolumn{8}{|l|}{ Bacillus sp. } \\
\hline UFPI B1-7 & $0 \mathrm{e}$ & $0 \mathrm{e}$ & $296 \mathrm{i}$ & $203 \mathrm{~h}$ & 499 i & $3 \mathrm{~h}$ & $9 \mathrm{~h}$ \\
\hline UFPI B1-8 & $0 \mathrm{e}$ & $\mathrm{Oe}$ & $472 \mathrm{~g}$ & $294 \mathrm{~g}$ & $766 \mathrm{~h}$ & $5 \mathrm{~h}$ & $15 \mathrm{e}$ \\
\hline UFPI B1-9 & $0 \mathrm{e}$ & $0 \mathrm{e}$ & $336 \mathrm{~h}$ & $381 \mathrm{f}$ & $717 \mathrm{~h}$ & $3 \mathrm{~h}$ & $11 \mathrm{~g}$ \\
\hline UFPI B3-1 & $0 \mathrm{e}$ & $0 \mathrm{e}$ & $243 \mathrm{i}$ & $343 f$ & $586 \mathrm{i}$ & $2 \mathrm{~h}$ & $7 i$ \\
\hline UFPI B3-3 & $0 \mathrm{e}$ & $0 \mathrm{e}$ & $410 \mathrm{~h}$ & $362 f$ & $772 \mathrm{~h}$ & $4 \mathrm{~h}$ & $13 \mathrm{f}$ \\
\hline \multicolumn{8}{|c|}{ Bradyrhizobium sp. } \\
\hline UFPI B3-4 & $165 b$ & $163 b$ & $1.330 \mathrm{~d}$ & $836 \mathrm{c}$ & $2.166 \mathrm{~d}$ & 35 e & $42 \mathrm{c}$ \\
\hline \multicolumn{8}{|l|}{ Enterobacter sp. } \\
\hline UFPI B5-4 & $0 \mathrm{e}$ & $0 \mathrm{e}$ & $396 \mathrm{~h}$ & $540 \mathrm{e}$ & $936 \mathrm{~g}$ & $3 \mathrm{~h}$ & $12 \mathrm{f}$ \\
\hline UFPI B5-6 & $0 \mathrm{e}$ & $0 \mathrm{e}$ & $273 i$ & $467 \mathrm{e}$ & $740 \mathrm{~h}$ & $3 \mathrm{~h}$ & $8 \mathrm{~h}$ \\
\hline UFPI B5-7A & $104 \mathrm{c}$ & $98 \mathrm{c}$ & $776 f$ & $695 d$ & $1.471 \mathrm{f}$ & $9 \mathrm{~g}$ & $24 d$ \\
\hline \multicolumn{8}{|l|}{ Pseudomonas sp. } \\
\hline UFPI B5-8A & $0 \mathrm{e}$ & $0 \mathrm{e}$ & $373 \mathrm{~h}$ & 453 e & $826 \mathrm{~g}$ & $4 \mathrm{~h}$ & $11 \mathrm{~g}$ \\
\hline \multicolumn{8}{|l|}{ Paenibacillus sp. } \\
\hline UFPI B1-5 & $0 \mathrm{e}$ & $0 \mathrm{e}$ & $305 i$ & $233 \mathrm{~g}$ & $538 \mathrm{i}$ & $3 \mathrm{~h}$ & $9 \mathrm{~h}$ \\
\hline UFPI B3-5 & $155 b$ & $101 \mathrm{c}$ & $1.125 \mathrm{e}$ & $500 \mathrm{e}$ & $1.625 \mathrm{e}$ & $25 f$ & $38 c$ \\
\hline UFPI B3-7 & $68 d$ & $26 d$ & $343 \mathrm{~h}$ & $166 \mathrm{~h}$ & $509 i$ & $4 \mathrm{~h}$ & $11 \mathrm{~g}$ \\
\hline UFPI B4-3 & $159 b$ & $68 c$ & $345 \mathrm{~h}$ & $360 \mathrm{f}$ & $715 \mathrm{~h}$ & $7 \mathrm{~g}$ & $11 \mathrm{~g}$ \\
\hline UFPI B4-5 & $91 \mathrm{c}$ & $59 d$ & $503 \mathrm{~g}$ & $260 \mathrm{~g}$ & $763 \mathrm{~h}$ & $8 \mathrm{~g}$ & $16 \mathrm{e}$ \\
\hline UFPI B4-6 & $63 d$ & $31 \mathrm{~d}$ & $321 \mathrm{~h}$ & $256 \mathrm{~g}$ & $577 i$ & $4 \mathrm{~h}$ & $10 \mathrm{~g}$ \\
\hline UFPI B4-7 & $0 \mathrm{e}$ & $0 \mathrm{e}$ & $316 \mathrm{~h}$ & $301 \mathrm{~g}$ & $617 i$ & $4 \mathrm{~h}$ & $10 \mathrm{~g}$ \\
\hline UFPI B 6-1 & $0 \mathrm{e}$ & $0 \mathrm{e}$ & $415 \mathrm{~h}$ & $373 \mathrm{f}$ & $788 \mathrm{~h}$ & $4 \mathrm{~h}$ & $13 \mathrm{f}$ \\
\hline UFPI B6-3 & $0 \mathrm{e}$ & $0 \mathrm{e}$ & $326 \mathrm{~h}$ & $420 \mathrm{f}$ & $746 \mathrm{~h}$ & $4 \mathrm{~h}$ & $10 \mathrm{~g}$ \\
\hline UFPI B6-9B & $0 \mathrm{e}$ & $0 \mathrm{e}$ & $278 \mathrm{i}$ & $433 \mathrm{e}$ & $711 \mathrm{~h}$ & $3 \mathrm{~h}$ & $9 \mathrm{~h}$ \\
\hline UFPI B7-3 & $0 \mathrm{e}$ & $0 \mathrm{e}$ & $476 \mathrm{~g}$ & $380 \mathrm{f}$ & $856 \mathrm{~g}$ & $5 \mathrm{~h}$ & $15 \mathrm{e}$ \\
\hline UFPI B7-5 & $0 \mathrm{e}$ & $0 \mathrm{e}$ & $216 i$ & $324 \mathrm{~g}$ & $540 i$ & $3 \mathrm{~h}$ & $7 i$ \\
\hline UFPI B7-6 & $56 d$ & $45 d$ & $350 \mathrm{~h}$ & $373 f$ & $723 \mathrm{~h}$ & $5 \mathrm{~h}$ & $11 \mathrm{~g}$ \\
\hline UFPI B7-7B & $0 \mathrm{e}$ & $0 \mathrm{e}$ & $398 \mathrm{~h}$ & $476 \mathrm{e}$ & $874 \mathrm{~g}$ & $5 \mathrm{~h}$ & $12 \mathrm{f}$ \\
\hline UFPI B7-8 & $0 \mathrm{e}$ & $0 \mathrm{e}$ & $286 \mathrm{i}$ & $481 \mathrm{e}$ & $767 \mathrm{~h}$ & $3 \mathrm{~h}$ & $9 \mathrm{~h}$ \\
\hline UFPI B7-9 & $0 \mathrm{e}$ & $0 \mathrm{e}$ & $345 \mathrm{~h}$ & $370 \mathrm{f}$ & $715 \mathrm{~h}$ & $4 \mathrm{~h}$ & $11 \mathrm{~g}$ \\
\hline \multicolumn{8}{|c|}{ Bradyrhizobium sp. ${ }^{a}$} \\
\hline INPA 03-11B & $226 \mathrm{a}$ & $237 \mathrm{a}$ & $3.620 \mathrm{a}$ & $1.447 \mathrm{~b}$ & $5.067 \mathrm{~b}$ & $156 \mathrm{a}$ & $114 a$ \\
\hline UFLA 03-84 & $45 d$ & $82 \mathrm{c}$ & $2.130 \mathrm{c}$ & $410 f$ & $2.540 \mathrm{c}$ & $82 \mathrm{c}$ & $67 b$ \\
\hline BR 3267 & $41 \mathrm{~d}$ & $109 \mathrm{c}$ & $1.385 \mathrm{~d}$ & $838 c$ & $2.223 d$ & $53 d$ & $44 \mathrm{c}$ \\
\hline $\mathrm{N}\left(52.5 \mathrm{mg} \mathrm{L}^{-1}\right)$ & $0 \mathrm{e}$ & $0 \mathrm{e}$ & $3.195 b$ & $2.103 \mathrm{a}$ & $5.298 \mathrm{a}$ & $136 b$ & $100 \mathrm{a}$ \\
\hline $\mathrm{N}\left(5.25 \mathrm{mg} \mathrm{L}^{-1}\right)$ & $0 \mathrm{e}$ & $0 \mathrm{e}$ & $198 \mathrm{i}$ & $126 \mathrm{~h}$ & $324 j$ & $2 \mathrm{~h}$ & $6 i$ \\
\hline CV (\%) & 34.09 & 2.46 & 9.63 & 9.58 & 6.20 & 7.72 & 4.49 \\
\hline
\end{tabular}

Means followed by the same letter in the column are not different at $p \leq 0.05$; aPositive controls for nodulation.

inoculated with these strains were similar to those obtained from non-nodulating strains and the control with low mineral $\mathrm{N}$ concentration.

For EFN, the inoculant strain INPA 03-11B was different from the others, showing efficiency similar $(p \leq$ 0.05 ) to the control with high mineral $\mathrm{N}$ concentration (Table 4). Strain UFLA 03-84 exhibited higher $(p \leq 0.05)$ efficiency than the other strains, except for INPA 03-11B. Strains UFPI B3-4 and UFPI B3-5 presented similar efficiency values that were also higher $(p \leq 0.05)$ than those obtained from the other strains, grouping with inoculant strain BR 3267. Ninety-two percent of the strains evaluated can be considered efficient to promote cowpea growth when compared to the control with low mineral $\mathrm{N}$ concentration (Table 4).

\section{Discussion}

The selection of bacterial strains able to act in biological processes that promote crop growth of agronomic interest, such as cowpea, is an important strategy to obtain biotechnological products that can contribute to reducing the use of chemical fertilizers, consequently reducing production costs and environmental impact. 
In the present study, we tested the capacity of strains belonging to five bacterial genera (Bacillus, Bradyrhizobium, Enterobacter, Paenibacillus and Pseudomonas) (Table 1), isolated from soils of floodplains located in the Brazilian savannas, to perform different phytostimulating biological processes. Most strains (65 \%) evaluated were able to act in both solubilizing $\mathrm{Ca}$ phosphate and producing IAA in 79 medium with tryptophan (Tables 2 ,3). Regarding BNF, no strain presented free-living $\mathrm{N}_{2}$ fixation and only eight formed efficient symbiosis with cowpea. In addition to $\mathrm{LO}$, there are other free-living $\mathrm{N}_{2}$ fixation media; however, they were not evaluated in this study. Besides, these strains could have a different behavior in complex soil conditions. Evaluating the ability of bacteria adapted to adverse conditions, such as high temperatures and temporary flooding conditions, to solubilize insoluble inorganic phosphates is critical for selecting strains that can contribute to increasing plant growth in these environments using higher availability of soluble P. In selecting these bacteria, in vitro evaluation is an important step to test ability and indicate the most promising strains to perform the process. In the present study, the ability of strains that solubilized $\mathrm{Ca}$ phosphate ranged from low to medium and the ability of strains that solubilized Al phosphate was low (Table 2). No strain was able to solubilize Fe phosphate. These results corroborate findings reported in the scientific literature for bacteria isolated from cowpea nodules (Marra et al., 2012; Oliveira-Longatti et al. (2014). Marra et al. (2012) tested the ability of symbiotic and non-symbiotic strains in GELP to solubilize inorganic phosphates in solid medium. The authors showed that among the strains that solubilize $\mathrm{Ca}$ and $\mathrm{Al}$ phosphates, the solubilization indices ranged from low to medium and no strain solubilized Fe phosphate.

Some studies have indicated solubilization of insoluble inorganic phosphates by symbiotic and non-symbiotic bacteria as a promising alternative to increase $\mathrm{P}$ availability for plants and promote plant growth (Vessey, 2003; Oliveira-Longatti et al., 2013). In this study, strains UFPI B5-6 (Enterobacter sp.) and UFPI B5-8A (Pseudomonas sp.) exhibited the highest indices of $\mathrm{Ca}$ phosphate solubilization in vitro (3.54 and 2.32, respectively) (Table 2) and are indicated for future experiments in vivo to evaluate their contribution relative to $\mathrm{P}$ availability in the soil. Oliveira-Longatti et al. (2014) also reported Ca phosphate solubilization by strains of Enterobacter sp. (UFLA 03-16 and UFLA 03-27) and Pseudomonas sp. (UFLA 03-22); however, the solubilization indices were lower than those obtained in this study for these two genera.

The ability to synthesize IAA, a phytohormone belonging to the auxin group, is extensively widespread among bacteria associated with plants, both symbiotic and non-symbiotic. However, the quantity of synthesized IAA is highly variable among and within genera and species (Oliveira-Longatti et al., 2014). Additionally, various factors, including presence and/or concen- tration of tryptophan, temperature, $\mathrm{pH}$, concentration and source of $\mathrm{C}$ and/or other nutrients, can interfere both in the ability to synthesize IAA and in the quantity produced in culture medium (Ona et al., 2005; Patil et al., 2011; Oliveira-Longatti et al., 2014). In this study, for most strains evaluated, IAA synthesis was obtained when the culture media (DYGS and 79) were supplemented with amino acid tryptophan (Table 3). This response may be related to the fact that tryptophan is considered the main precursor for biosynthesis pathways of IAA by bacteria. At least five IAA biosynthesis pathways by symbiotic bacteria and/or those associated with plants have been described, four of which are dependent on the amino acid tryptophan: indole-3-pyruvate (IpyA), indole-3-acetamide (IAM), tryptamine (TAM) and indole-3-acetonitrile (IAN) (Spaepen et al., 2007).

Additionally, not only supplementation with tryptophan but also compositions of the culture media used affect both the IAA biosynthesis ability and its quantity synthesized. In the absence of tryptophan supplementation, seven strains and the positive control (BR 11001 ${ }^{\mathrm{T}}$ ) were able to synthesize IAA in the DYGS medium, whereas only BR $11001^{\mathrm{T}}$ showed this ability in the 79 medium. On the other hand, in presence of tryptophan, 79 medium stimulated IAA production in a greater number of strains and at a higher quantity compared with the DYGS medium (Table 3). Possibly, the greater IAA synthesis in DYGS medium compared with the 79 medium in absence of tryptophan supplementation may be related to the quantity of yeast extract added to these media. Yeast extract is an amino acid-rich source, including tryptophan. Thus, the higher quantity of yeast extract added to the DYGS medium (2 $\left.\mathrm{g} \mathrm{L}^{-1}\right)$, which corresponds to fivefold the quantity added to the 79 medium $10.4 \mathrm{~g}$ $\mathrm{L}^{-1}$, might have activated some of the IAA biosynthesis pathways in certain bacteria, due to the higher supply of tryptophan in the DYGS medium. Another explanation is related to the source and quantities of nutrients added to each culture medium, which may affect the expression of biosynthesis genes and the quantity of IAA synthesized by different bacteria (Kumar and Ram, 2012; Mandal et al., 2007; Patil et al., 2011).

IAA is one of the main hormones that regulates plant growth. It acts in both phytostimulation and inhibition depending on the concentrations to which the plants are exposed (Patil et al., 2011). In this study, there was wide variability in the ability to synthesize IAA among the bacteria evaluated, suggesting that they exhibit potential to be used as inoculants to promote crop growth of agricultural interest.

We found different responses for most strains evaluated regarding nodulation and promoting cowpea growth (Table 4). Eight strains, belonging to three different genera (Bradyrhizobium, Enterobacter and Paenibacillus) nodulated cowpea plants, which indicates that this species is promiscuous, corroborating other studies (Guimarães et al., 2012; Jaramillo et al., 2013; Marra et al., 
2012; Soares et al., 2014). Cowpea nodulation by strains belonging to genus Bradyrhizobium is already well documented and strains currently authorized by MAPA as inoculants for this crop belong to this genus. Genera Enterobacter and Paenibacillus usually occur endophytically in legume nodules, however, their ability to nodulate is not common. Nevertheless, nodulation by these genera was recently reported in cowpea (Jaramillo et al., 2013; Marra et al., 2012; Soares et al., 2014). Possibly, some endophytic nodule bacteria can evolve into symbiotic bacteria and acquire the ability to nodulate via horizontal transfer of symbiotic genes from nodulating bacteria (Li et al., 2008; Shiraishi et al., 2010). Most nodulating strains belonging to Paenibacillus and Enterobacter genera showed low symbiotic efficient in our study.

A greater number of strains was expected to nodulate cowpea because they were isolated from this plant species. However, isolation of non-symbiotic endophytic bacteria in surface-sterilized legume nodules is well documented in the scientific literature (Kan et al., 2007; Li et al., 2008; Shiraishi et al., 2010) and these bacteria can affect plant growth via different mechanisms, as they can stimulate or inhibit plant growth (Anjum et al., 2011) or produce no effect (Li et al., 2008).

Regarding the strain able to nodulate cowpea, there was high variability among their symbiotic efficiency (Table 4). UFPI B3-4 (Bradyrhizobium sp.) and UFPI B3-5 (Paenibacillus sp.) strains exhibited similar efficiency to one of the inoculant strains (BR 3267). Among the strains that are currently used as cowpea inoculants (INPA 03-11B, UFLA 03-84 and BR 3267), the efficiency of INPA 03-11B is noteworthy, as it promoted higher shoot dry matter yield and $\mathrm{N}$ accumulation in the shoots than did the control with high mineral $\mathrm{N}$ concentration (Table 4). Thus, the present study is one more investigation that confirms the potential of this strain to provide all $\mathrm{N}$ necessary for cowpea development, without requiring the use of $\mathrm{N}$ fertilizers, which, in addition to being expensive, can contaminate the environment when improperly managed.

Non-nodulating strains UFPI B1-8, UFPI B1-9, UFPI B3-3 (Bacillus sp.), UFPI B5-4 (Enterobacter sp.), UFPI 5-8A (Pseudomonas sp.), UFPI B6-1, UFPI B63, UFPI B7-3 and UFPI B7-7B (Paenibacillus sp.) were very efficient in promoting cowpea growth (Table 4). These strains and nodulating strains UFPI B3-7, UFPI B4-6 and UFPI B7-6 (Paenibacillus sp.) most likely act as plant growth promoters through biological processes different from $\mathrm{BNF}_{\text {, as }} \mathrm{N}$ accumulation in the shoots in the treatments inoculated with these strains was similar to the uninoculated control with low $\mathrm{N}$ concentrations. Thus, had there been no $\mathrm{N}$ limitation, the effect of these strains on plant growth might have been greater. We suggest future assays that combine different $\mathrm{N}$ doses and inoculation with the nodulating and non-nodulating strains used in this study. All non-nodulating strains and inefficient nodulating strains (UFPI B3-7, UFPI B4-6 and UFPI B7-6) that promoted both shoot and root growth of cowpea were positive regarding the ability to solubilize Ca phosphate (Table 2) and synthesize IAA (Table 3), except for strain UFPI B7-9 that was unable to perform both processes and strain UFPI B3-3, which was unable to synthesize IAA. However, because $\mathrm{P}$ sources used in the nutritional solution in the experiment are soluble, plant growth promotion may be more related to IAA production, although not all strains that produced IAA promoted shoot growth of cowpea. These bacteria might have also contributed to plant growth via other phytostimulating biological processes, which were not evaluated in this study. Another explanation is that other $\mathrm{C}$ source of root exudates could stimulate the production of phytohormones, especially in the case of strains UFPI B3-3 and UFPI B7-9.

Overall, considering that $92 \%$ of the strains inoculated in cowpea exhibited higher efficiency compared to the control with low mineral $\mathrm{N}$ concentration, it can be inferred that the floodplain soils of the Brazilian savannas favor the occurrence of symbiotic and endophytic bacteria that can perform one or more phytostimulating processes and promote plant growth, with potential to be used as biotechnological products in agriculture. In future studies, strains that promoted most cowpea growth will be evaluated in other crops of agricultural interest and in field experiments to test their potential in presence of interactions with other edaphic microorganisms and other soil components.

\section{Acknowledgments}

The authors thank the National Council for Scientific and Technological Development [Conselho Nacional de Desenvolvimento Científico e Tecnológico (CNPq)] and Coordination for the Improvement of Higher Education Personnel [Coordenação de Aperfeiçoamento de Pessoal de Nivel Superior (CAPES)] for financial support and for granting scholarships. Minas Gerais State Foundation for Research Support [Fundação de Amparo à Pesquisa do Estado de Minas Gerais (FAPEMIG)] is also acknowledged by financial support.

\section{References}

Anjum, M.A.; Zahir, Z.A.; Arshad, M.; Ashraf, M. 2011. Isolation and screening of rhizobia for auxin biosynthesis and growth promotion of mung bean (Vigna radiata L.) seedlings under axenic conditions. Soil \& Environment 30: 18-26.

Asghar, H.N.; Zahir, Z.A.; Arshad, M.; Khaliq, A. 2002. Relationship between in vitro production of auxins by rhizobacteria and their growth promoting activities in Brassica juncea L. Biology and Fertility of Soils 35: 231-237.

Berraquero, F.R.; Baya, A.M.; Cormenzana, A.R. 1976. Establishment of indices for the study of phosphate solubilization by soil bacteria. Ars Pharmaceutica 17: 399-406.

Carson, K.C.; Holliday, S.; Glenn, A.R.; Dilworth, M.J. 1992. Siderophore and organic acid production in root nodule bacteria. Archives of Microbiology 157: 264-271. 
Dreyfus, B.L.; Elmerich, C.; Dommergues, Y.R. 1983. Free-living Rhizobium strain able to grow on $\mathrm{N}_{2}$ as the sole nitrogen source. Applied and Environmental Microbiology 45: 711-713.

Ferreira, D.F. 2011. Sisvar: a computer statistical analysis system. Ciência e Agrotecnologia 35: 1039-1042.

Ferreira, L.V.M.; Nobrega, R.S.A.; Nobrega, J.C.A.; Aguiar, F.L; Moreira, F.M.S.; Pacheco, L.P. 2013. Biological nitrogen fixation in production of Vigna unguiculata (L.) Walp family farming in Piauí, Brazil. Journal of Agricultural Science 4: 153-160.

Fred, E.B.; Waksman, S.A. 1928. Laboratory Manual of General Microbiology: With Special Reference to the Microorganisms of the Soil. McGraw-Hill, New York, NY, USA.

Guimarães, A.A.; Jaramillo, P.M.D.; Nóbrega, R.S.A.; Florentino, L.A.; Silva, K.B.; Moreira, F.M.S. 2012. Genetic and symbiotic diversity of nitrogen fixing bacteria isolated from agricultural soils in the western Amazon by using cowpea as the trap plant. Applied and Environmental Microbiology 78: 6726-6733.

Hoagland, D.; Arnon, D.I. 1950. The water culture method for growing plants without soil. University of California, Berkeley, CA, USA. (AES Circular, 347)

Jaramillo, P.M.D.; Guimarães, A.A.; Florentino, L.A.; Silva, K.B.; Nóbrega R.S.A.; Moreira, F.M.S. 2013. Symbiotic nitrogen-fixing bacterial populations trapped from soils under agroforestry systems in the western Amazon. Scientia Agricola 70: 397-404.

Kan, F.L.; Chen, Z.Y.; Wang, E.T.; Tian, C.F.; Sui, X.H.; Chen, W.X. 2007. Characterization of symbiotic and endophytic bacteria isolated from root nodules of herbaceous legumes grown in Qinghai-Tibet plateau and in other zones of China. Archives of Microbiology 188: 103-115.

Kumar, P.R.; Ram, M.R. 2012. Production of indole acetic acid by Rhizobium isolates from Vigna trilobata (L) Verdc. African Journal of Microbiology Research 6: 5536-5541.

Lane, D.J. 1991. 16S/23S rRNA sequencing, p. 115-148. In: Stackebrandt, E.; Goodfellow, M., eds. Nucleic acid techniques in bacterial systematics. Wiley, New York, NY, USA.

Li, J.H.; Wang, E.T.; Chena, W.F.; Chena, W.X. 2008. Genetic diversity and potential for promotion of plant growth detected in nodule endophytic bacteria of soybean grown in Heilongiiang province of China. Soil Biology \& Biochemistry 40: 238-246.

Lima, A.S.; Nobrega, R.S.A.; Barberi, A.; da Silva, K.; Ferreira, D.F.; Moreira, F.M.S. 2009. Nitrogen-fixing bacteria communities occurring in soils under different uses in the Western Amazon region as indicated by nodulation of siratro (Macroptilium atropurpureum). Plant and Soil 319: 127-145.

Mandal, S.M.; Mondal, K.C.; Dey, S.; Pati, B.R. 2007. Optimization of cultural and nutritional conditions for indole 3-acetic acid (IAA) production by a Rhizobium sp. isolated from root nodules of Vigna mungo (L.) Hepper. Research Journal of Microbiology 2: $239-246$

Marra, L.M.; Soares, C.R.F.S.; Oliveira, S.M.; Ferreira, P.A.A.; Soares, B.L.; Carvalho, R.F.; Lima, J.M.; Moreira, F.M.S. 2012. Biological nitrogen fixation and phosphate solubilization by bacteria isolated from tropical soils. Plant and Soil 353: 289-307.

Martins, L.M.V.; Xavier, G.R.; Rangel, F.W.; Ribeiro, J.R.A.; Neves, M.C.P.; Morgado, L.B.; Rumjanek, N.G. 2003. Contribution of biological nitrogen fixation to cowpea: a strategy for improving grain yield in the semi-arid region of Brazil. Biology and Fertility of Soils 38: 333-339.
Moreira, F.M.S.; Cruz L.; Faria, S.M.; Marsh, T.; MartinezRomero, E.; Pedrosa, F.O.; Pitard, R.M.; Young, J.P.W. 2006. Azorhizobium doebereiner sp. Nov. microsymbiont of Sesbania virgata (Caz.) Pers. Systematic and Applied Microbiology 29: 197-206.

Nautiyal, C.S. 1999. An efficient microbiological growth medium for screening phosphate solubilizing microorganisms. FEMS Microbiology Letters 170: 265-270.

Oliveira-Longatti, S.M.; Marra, L.M.; Moreira, F.M.S. 2013. Evaluation of plant growth promoting traits of Burkholderia and Rhizobium strains isolated from Amazon soils for their coinoculation in common bean. African Journal of Microbiology Research 7: 948-959.

Oliveira-Longatti, S.M.; Marra, L.M.; Soares, L.B.; Bomfeti, C.A.; Silva K.; Ferreira P.A.A.; Moreira, F.M.S. 2014. Bacteria isolated from soils of the western Amazon and from rehabilitated bauxite-mining areas have potential as plant growth promoters. World Journal of Microbiology and Biotechnology 29: 1-12.

Ona, O.; Impe, J.V.; Prinsen, E.; Vanderleyden, J. 2005. Growth and indole-3-acetic acid biosynthesis of Azospirillum brasilense Sp245 is environmentally controlled. FEMS Microbiology Letters 246: 125-132.

Patil, N.B.; Gajbhiye, M.; Ahiwale, S.S.; Gunjal, A.B.; Kapadnis, B.P. 2011. Optimization of Indole 3 acetic acid (IAA) production by Acetobacter diazotrophicus L1 isolated from sugarcane. International Journal of Environmental Science 2: 295-302.

Radwan, T.; Mohamed, Z.K.; Reis, V.M. 2002. Production of indole-3-acetic acid by different strains of Azospirillum and Herbaspirillum spp. Symbiosis 31: 39-54.

Rufini, M.; Silva, M.A.P.; Ferreira, P.A.A.; Cassetari, A.S.; Soares, B.L.; Andrade, M.J.B.; Moreira, F.M.S. 2013. Symbiotic efficiency and identification of rhizobia which nodulate cowpea in eutroferric Red Latosol. Biology and Fertility of Soils 50: $115-122$.

Sarwar, M.; Kremer, R.J. 1995. Enhanced suppression of plant growth through production of L-tryptophan-derived compounds by deleterious rhizobacteria. Plant and Soil 172: 261-269.

Shiraishi, A.; Matsushita, N.; Hougetsu, T. 2010. Nodulation in black locust by the Gammaproteobacteria Pseudomonas sp. and the Betaproteobacteria Burkholderia sp. Systematic and Applied Microbiology 33: 269-274.

Soares, B.L.; Ferreira, P.A.A.; Oliveira-Longatti, S.M.; Marra, L.M.; Rufini, M.; Andrade, M.J.B.; Moreira, F.M.S. 2014. Cowpea symbiotic efficiency, $\mathrm{pH}$ and aluminum tolerance in nitrogen-fixing bacteria. Scientia Agricola 71: 171-180.

Spaepen, S.; Vanderleyden, J.; Remans, R. 2007. Indole-3-acetic acid in microbial and microorganism-plant signaling. FEMS Microbiology Reviews 31: 425-448.

Vessey, J.K. 2003. Plant growth promoting rhizobacteria as biofertilizers. Plant and Soil 255: 571-586.

Vincent, J.M. 1970. A manual for the practical study of the rootnodule bacteria: a manual for the practical study of the rootnodule bacteria. IBP, Houston, TX, USA. (IBP Handbook). 